\title{
APPLICABLE LIMITATIONS ON THE CRIMINAL CODE BASED ON THE 1945 CONSTITUTION, LAW NO. 1 OF 1946 AND THE GOVERNMENT REGULATION NO. 2 OF 1945
}

\author{
${ }^{1}$ Ade Adhari, ${ }^{2}$ Tundjung Herning SB \\ ${ }^{1}$ Faculty of Law, Universitas Tarumanagara, Jakarta, adea@fh.untar.ac.id \\ ${ }^{2}$ Faculty of Law, Universitas Tarumanagara, Jakarta, tundjunghidayat@yahoo.com
}

\begin{abstract}
The enactment of Criminal Code (Wetboek van Strafrecht) in Indonesia is based on the 1945 Constitution, Law No. 1 of 1946 and Government Regulation No. 2 of 1945. The existence of these regulations not only gives legitimacy to the implementation of the Criminal Code, but also provides 'boundary signs' in implementing them. This paper aims to examine the limitations of the enactment of the Criminal Code based on various provisions. The limiting signs include: first, the enactment of the Criminal Code is temporary until the Criminal Code is established based on the 1945 Constitution. This means that the Draft Law on the Criminal Code must be ratified immediately. It is a form of carrying out the mandate to renewal of criminal law as stated in the constitution. Second, there is a need to examine the norms of criminal law in the Criminal Code before it is applied (whether the criminal law norms are in accordance with the criteria "does not conflict with the position of the Republic of Indonesia as an independent state or not in conflict with the Constitution"), and third, the application of the articles in the Criminal Code must remain in the Indonesian context.
\end{abstract}

Keywords: Code Penal; The Limiting Signs

\section{Introduction}

Indonesia has not yet to fullfill their noble wish to be free and released from all the chains of colonialism in the field of law with the colonial Criminal Code still being used until this day.The noble wish that was mentioned earlier was somehow stated in the opening of the 1945 Indonesian Constitution that stated ".... With the grace of God Almighty and with the spirit of noble desires, so that national life can be free, the people of Indonesia hereby declare their independence...." The indenpendence that is desired in the opening surely meant being independent in terms of law, which is to be free or independent for the colonial law.

The reality of our current situation that is the opposite of our noble desires is something that can't be denied. This is what is very commonly known as the discrepancy between das sollen and das sein. It is fair if Piepers states Met die Code Penal (read W.v.S.Ned.) ging het als een broek die eerst door vader wordt gedragen, dan overgaat op den oudsten en vervolgens met een lap er op, op den tweede zoon”. Which means "Code Penal or Criminal Code is like a pair of 
pants that was once used by the father, and then passed on to his first born and after that with a patch of cloth will be passed on to his second born" 1

Paul H. Robinson et.al., argued Criminal law codifies social norms, which manifest as perceptions that can be empirically measured. ${ }^{2}$ The current Criminal Code comes from the colonial government, so the norms in it are a reflection of colonial society. Until this day, the criminal code that was passed on by the colonials is still regulated with a few changes for time to time. Those changes include Law No. 1/1946 (Chapter VIII) : Article 94 Chapter IX Book I of the criminal code about the definition of 'Dutch Ship' (Nederlandsche Schepen) was erased; Law No. 20/1946 (Article I) : the main criminal offences in article 10 sub a of the criminal code was added; Law No. 73/1958 (Article II) : article 52a (about the criminal charge for committing a crime using the national flag) was added; Law No. 4/1976 : Article 3 of the criminal code (expanded to aircrafts) was altered and was added extension to the Teritorial Principle and the Universal Principle in Article 4 (expanded to flight crimes); article 95a (the definition of 'Indonesian Aircrafts'), article 95b (the definition of 'in flights'), and article 95c (the definiton of 'in office'), and etc.

The changes that have been done towards the criminal code does not fully releases Indonesia from the principles of the colonial penal code. Eventhough Law No. 1 of 1946 has tried to adapt with the independence atmosphere, the principles and the basis of criminal law are still based on criminal law and the practice of colonial criminal law. Basically, the principles and basics of criminal law and colonial criminal law still survive in Indonesia.

The enactment of the criminal code which is a colonial inheritance is based on the 1945 Constitution, ${ }^{3}$ Law No. 1 of 1946 about the Criminal Regulation and the Government Regulation No. 2 of 1945 about the Former Government Agencies and Regulations. The Transitional Rules of the 1945 Constitution are the constitutional basis for the enactment of the criminal code. Constitutionally speaking, the implementation of the criminal code against the offencer that commited criminal offences based on what has been regulated in the constitution. Meanwhile the

1 J.E. Sahetapy, Legal Reform Must Embody the Pancasila, in the Judicial Commission of the Republic of Indonesia, Dialectics for the Renewal of the National Legal System (Jakarta: Secretariat General of the Judicial Commission of the Republic of Indonesia, 2012).

2 et.al. James T. Graves, "Perception versus Punishment in Cybercrime," Journal of Criminal Law and Criminology 109, no. 2 (2019).

3 Look at Article II of the Transitional Rules of the 1945 Constitution prior to the Amendment to the 1945 Constitution, which later this provision in the 1945 Constitution Post Amendments contained in Article I of the Transitional Rules 
provisions in Law No. 1 of 1946 and PP No. 2 of 1945 became a juridical basis for enacting the criminal code.

In addition to being a constitutional and juridical basis for the enactment of the criminal code, the three regulations also provide signs, guidelines or instructions. ${ }^{4}$ Signs, guidelines or instructions must be considered in enforcing and implementing the Criminal Code. In other words, as a guideline, these rules inform, give direction, guidance, or inspiration for how criminal law enforcement is carried out, about how the criminal justice system should be carried out.

The three regulations that was mentioned before, contains good things that must be considered in applying criminal code in Indonesia. But unfortunately the signs were often ignored in the law enforcement. Law enforcement is more defined as a reading or implementing the principles of the criminal code in letterlijk. Enforcing the criminal law means enforcing every letter and word that has been normatively formulated in the criminal code. In light of the foregoing this paper reviews the guidelines that must be considered in implementing the Criminal Code in Indonesia. Based on this understanding the title of this article can be concluded as "Applicable Limitations on the Criminal Code based on the 1945 Constitution, Law No.1 of 1946 and the Government Regulation No. 2 of 1945"

\section{Discussion}

Indonesia is a country whose legal system is heavily influenced by a family of legal systems called civil law. One of the things is marked by the codification of criminal law. Talking about the codification of criminal law, it is necessary to begin by understanding the meaning of criminal law. The criminal law sets boundaries both to our behavior and to the power of the state to coerce and punish us. ${ }^{5}$ Regarding this view, William Tetley stressed that Civil law may be defined as that legal tradition which has its origin in Roman law, as codified in the Corpus Juris Civilis of Justinian, and as subsequently developed in Continental Europe and around the world. Civil law eventually divided into two streams: the codified Roman law (as seen in the French Civil Code of 1804 and its progeny and imitators - Continental Europe, Québec and Louisiana being examples); and uncodified Roman law (as seen in Scotland and South Africa). Civil law is

4 General Explanation of the Third Item Law No. 1 of 1946 referred to Article 5 as "guidance".

5 William Wilson, Criminal Law (London: Perason Education Limited, 2017). 
highly systematised and structured and relies on declarations of broad, general principles, often ignoring the details. ${ }^{6}$

Finbarr McAuley explained the history of the birth of codification in a legal system Historically speaking, the practice of codification dates back at least to Babylonian times; the Code of Hammurabi is believed to have been promulgated c. $1700 \mathrm{BC}$ and may have had Sumerian and Akkadian antecedents. In contrast, the term codification was coined as recently as 1815 , by Jeremy Bentham in a letter to Tsar Alexander. ${ }^{789}$ Next Barry Wright put forward the importance of Jeremy Bentham's role in the idea of codification. Barry Wright said:

Codificationwas an important aspect of Jeremy Bentham's ambitious law reform proposals........ Bentham advocated a comprehensive code of universal applicability, arguing that the principles of utility that anchored codification were relevant to places as diverse as England and Bengal. ${ }^{10}$

Related to the meaning of the codification itself, it is important to understand what was conveyed by F. Wieacker who said "the Codification was not focused on gathering, compiling, improving or reforming the existent scientific or prescientific law - as the former German reforms or Roman and Spanish compilations-, but planning a better society by means of new systematic and creative law". ${ }^{11}$ Nicholas Kasirer, a law professor from McGill University, defines codification as a modem legislative technique and on how historically contingent this legislative technique may in fact be. ${ }^{12}$.

Maintaining codification in criminal law is mainly due to the various benefits that have resulted. Regarding the benefits of cofification, Finbarr McAuley stated the following matters: ${ }^{13}$

In both legal traditions the aims of criminal law codification have remained more or less constant since the first modern codes were promulgated: 1) to bring order to the sources of the criminal law by eliminating confusion and uncertainty; 2) to improve access to the

6 William Tetley, "Mixed Jurisdiction: Common Law vs Civil Law (Codified and Uncodified)," Unif. L. Rev 3 (1993): 596.

7 Et.al Finbar McAuley, "Codifying the Criminal Law, Expert Group on the Codification of the Criminal Law" (Dublin, 2004).

8 Jeremy Bentham, "Paper Relative to Codification and Public Instruction: Including Correspondence with the Russian Emperor, and Divers Constituted Authorities in the American United States, No. XII,” Jeremy Bentham to Emperor of the All Russias, Letter II, n.d.

9 John Bowring, "The Works of Jeremy Bentham, Vol. 4.," The Superntedence of His Executor, n.d.

10 Barry Wright, "Bentham's Enlightened Despotic Legislator and Colonial Rule: Macaulay and India Penal Code," in A Model Penal Code Adhering to the Philosophy of Macaulay: A Project to Mark the 150th Annivarsary of the Indian Penal Code., 2010, 1.

11 Maria Luisa Murillo, "The Evolution of Codification in the Civil Law Legal Systems: Towards Decodification and Recodification," Journal Transnational Law \& Policy 11, no. 1 (n.d.): 3.

12 Nicholas Kasirer, "Canada's Criminal Law Codification Viewed and Reviewed," McGill Law Journal, 1990, 866.

13 Finbarr McAuley, "Meeting the Challenge of Codifying the Criminal Law," in The 22nd International Conference of the International Society for the Reform of Criminal Law, 2008. 
criminal law by digesting it into a single authoritative instrument; 3 ) to reinforce the democratic legitimacy of the criminal law by recasting it in a modern enactment binding on judges and citizens alike; 4) to enhance comprehension of the criminal law by rendering it in a uniform drafting style and intelligible idiom; and 5) to promote conceptual consistency in the interpretation and application of the law by standardising the meaning of key terms used across the spectrum of criminal offences.

What was conveyed by Finbarr McAuley above shows that there are many benefits that result from the use of codification in criminal law. In the criminal law system in Indonesia, the use of the codification system is seen by the enactment of the Criminal Code from the colonial colonial legacy.

The study of the limits of the Criminal Code is important to do. Especially in criminal law enforcement practices in Indonesia, the Criminal Code is applied as it is, as if the Criminal Code is independent of the national legal system in force in this republic. In order to understand the limiting signs of the enactment of the Criminal Code, it is important to add the editorial article in the three regulations which contain limiting signs :

a. The 1945 Constitution

The 1945 Constitution has a very importatnt part in the national law system, so it has to be a reference to answer every problem, including the problems regarding the signs that acts as a limitation to the criminal code in Indonesia. Without paying attention to the 1945 constitution, the purpose of law enforcing will not be fullfilled. Why is it stated otherwise, because according to article 4 of the Law No.12 of 2011 about the formation of legislation, states that the 1945 Constitution of the Republic of Indonesia is the basic law in legislation. This means that the 1945 Constitution becomes the basic law for the Criminal Code. so that in the criminal law enforcement process, it cannot only refer to the Criminal Code but also the 1945 Constitution as the basis.

In Article II of the Transitional Rules of the 1945 Constitution prior to the Amendment to the 1945 Constitution which states "all existing State Agencies and Regulations are still in effect immediately, as long as no new provisions have been made according to this Constitution" which then this provision in the 1945 constitution post amandement article 1 transitional rules states "All existing laws and regulations are still in effect as long as no new provisions have been made according to this Constitution". 
b. Law No.1 of 1946

Article 5 of Law No.1 of 1946 states "criminal law regulations, in it's entirety or partly inoperable, or is contradicting with the standing of Republic of Indonesia as an independent country, or does not have any meaning, should be considered in it's entirety or partly temporarily inapplicable." Article $5^{14}$ according to the general explanation of Law No. 1 of 1946 section III is one of the guidelines that has to be considered by those who is using the criminal code. It was even stated that which path that has to be used to adjust the old regulations with current situation before those regulations can be modified or replaced. ${ }^{15}$

\section{c. Government Regulations No. 1 of 1945}

Article 1 of Government Regulations No. 1 of 1945 states “every state agencies and regulations that existed until the founding of the Republic of Indonesia on August 17th 1945 , as long as there's no new regulations, according to the constitution, it is still applicable as long as it is not contradicting with the consitution."

Based on the previous provisions, it can be concluded that there is a spirit of nationalism that is implemented in the 1945 constitution, Law No. 1 of 1946 and the Government Regulation No. 2 of 1945 as the limitation for the enactment of the criminal code. The spirit of nationalism is manifested with limitations in the form of :

a. The enactment of the criminal code in Indonesia is temporary

The enactment of the criminal code is temporary can be seen in the frase "before the regulations can be modified of replaced." Which is stated clearly in the general explanation

14 Besides being contained in Article 5, other instructions that must be considered are in Articles 3 and 4. Article 3 reads If in a criminal law regulation is written with the words "Nederlandsch-Indie" or "NederlandschIndisch (e) (en)", then the words- the words should read "Indonesie" or "Indonesishc (e) (en)". Whereas Article 4 states that if in a criminal law regulation a right, obligation, power or protection is given or a prohibition is addressed to an employee, entity, department and so on, which now no longer exists, then those rights, obligations, powers or protections must be considered to be given and the prohibition is addressed to employees, agencies, offices and so on, who must be considered to replace it.

15 The following is more complete the sound of the General Explanation of the Third Item of Law Number 1 of 1946 concerning Criminal Law Regulations: It is not necessary to explain, that all regulations that apply on March 8, 1942, should one by one as much as possible must be adjusted accordingly the current situation. This is carried out as far as possible against the Indonesian Criminal Code (Wetboek van Strafrecht voor NederlandschIndie). But the work is not possible at the same time carried out against all Regulations. In connection with that, then with articles III, IV and V of the plan given instructions even though it is far from perfect to those who must carry out the daily criminal law regulations, which way should be taken to adjust the old regulations with the present situation, before the regulations -the rules can be changed or replaced. 
section III Law No.1 of 1946. This provision is in line with article 1 of the Government Regulation No. 2 of 1946 “.....as there's no new regulations, according to the constitution, it is still applicable as long as it is not contradicting with the consitution.." Both of these regulations, are infact in line with the constitution.

Article II of the Transitional Rule of the 1945 Constitution prior to the amandment of the 1945 constitution states "every state agencies or regulations that existed will continue on being applicable, as long as there is no new regulations according to this constitution" which then in this regulation in the 1945 constitution prior to the amandment is in article I of the Transitional Rule states "every law regulations that existed is still applicable as long as there's no new regulations according to this constitution." So naturally in the 1963 National Law Seminar I produced a recommendation to strongly call for the completion of the codification of the national criminal law as soon as possible.

Unfortunately, the spirit to regulate the criminal code temporarily by making a draft of the criminal code seems to lead nowhere. On Monday, September 24th 2019 or 21 years after the demand of reformation 1998, students held a demonstration with the hashtag "Reformasi Dikorupsi" (Reformation is Corrupted). The actions carried out by students from all various regions in Indonesia, gave 7 insistence, i.e : 1) To reject the Draft Criminal Code, Minerals, Mining, Land, Correctional, Employment, Urgent Repeal of KPK and natural resources Laws, urging the adoption of the PKS Law and the protection of domestic workers; 2) To revoke the problematic KPK leader; 3) Refuse TNI (army) and the Indonesian police to occupy a civil service; 4) Stop militarism in Papua and other areas, to free the political prisoners immediately; 5) Stop the criminalization of activists; 6) Stop burning forests and to punish the corporates that burns forests; and 7) Resolve violations of human rights and adjudicate human rights criminals.

The criminal code draft became one of the regulation drafts that was rejected. There is a lot of articles in the criminal code draft that received objections based on the student's act. The articles that was rejected consist of offenses such as insulting the president or the vice president (article 218-220), adultery (article 417), rape (article 480), intercourse with a marriage license (article 418), living together before marriage (article 419) and so on.

The student's act was just not to object, they even made a petition called "Petisi Tolak RKUHP" (petition to object the criminal code draft) which was circulated around the media, including social media. For sure the act to object the criminal code draft is not in 
line with the constitution. In context this is important to be mentioned that there may never be a perfect criminal code draft, without any flaws as for the drafting team are imperfect. The thing that can be done is to accept RKUHP as a product of renewal which in the future must always be updated following the development of Indonesian society. The ratification of the criminal code draft is the final form of carrying out the mandate of the constitution which has not yet to be accomplished.

b. Testing The Norms of Criminal Law in The Criminal Code Before It is Applied Carrying out the criminal code cannot be done just by reading Book I that consists of algemeene leerstukken (the validitiy of a criminal regulation, trial, assistance, the things that revoke criminal charges, criminal sentencings and so on), Book II Crimes and Book III Violation, have to be tested first with the applied article. Borrowing the terms conveyed by Oemar Senoadji as quoted by Barda Nawawi Arief, the 1945 Constitution, Law no. 1 of 1946 and the Government Regulation No. 1 of 1945 as a "screening board" or "toetsteen" to test whether a criminal regulation has a right to live or not in the Republic of Indonesia. ${ }^{16}$.

This states that every criminal law norms that are to be applied in Indonesia must first be validated. The validity of criminal law norms in the Criminal Code according to Article 5 of Law No. 1 of 1946 was determined by criteria: ${ }^{17}$ 1) Entirely or partly now that can't work; 2) Contradicts with the standing of Republic of Indonesia as an independent country, or; 3) Does not have any meaning

If article 5 Law No.1 of 1946 consists of 3(three) criterias to enact the criminal code, article 1 of Government Regulation No.2 of 1945 contains one criteria which is "as long as it does not contradicts with the constitution." It means that the 1945 Constitution is as a stepping stone to regulate the criminal law norms that is in the criminal code. If it does contradicts with the 1945 constitution, the the criminal law norms cannot be enacted. It shows how important the existence of the constitutional court to make sure whether the criminal law norms in the criminal code contradicts with the 1945 constitution or not. The authority of the consitutional court is to perform the test pursuant to article $24 \mathrm{C}$ of the 1945 Constitution which is to test out regulations against the 1945 constitution.

16 Barda Nawawi Arief, Complementary Criminal Law I (Semarang: Pustaka Magister, 2012).

17 Barda Nawawi Arief, Perkembangan Sistem Pemidanaan Di Indonesia (Semarang: Master Library Publisher, 2011). 
Besides being tested by the constitutional court, while doing investigation, charges and trial, law enforcement officers should pay attention to the 1945 constitution while implementing the articles in the criminal code. The implementation of every article formulation in the criminal code is what should be done by the law enforcement officers. The article in the criminal code that contradicts with the 1945 constitution, for an example article 1 paragraph 1 of the criminal code consists of the legality principle. It states that "no action can be convicted unless by the power of the criminal code in the existed regulation, before the action was done."

Eddy O.S. Hiariej states there is only two meanings that is consisted in the legality principle and that is, every action can be convicted only if the criminal law regulates it (...wil een feit strafbaar zijn, dan moet het vallen onder een wettelijke strafbepaling...) and the power of the criminal code must not be applied retroactively (....Zo'n strafbepalin mag geen terugwerkende kracht hebben...). ${ }^{18}$. Based on the various views on the legality principle above, it is right to say that the legality principle is one of them regulating the source of law to declare an act as a criminal offense.

Pursuant to article 1 paragraph (1) of the criminal code, the source of law to state an act is considered to be a criminal offense is law regulations which is written law. This provisions is not in line with :

1) Pancasila

The principle of "Social Justice for All Indonesians" can be interpreted that Pancasila wants that the criteria for an action as a criminal offense are not just law regulations, but a sense of justice that lives in social life. This means that the law that lives in the community as a measure of social justice in order to declare a misconduct and deserves to be convicted. This philosophical foundation provides the basis for justification to state, that justice cannot only be measured based on what is formulated by the law normatively in this case the Criminal Code, but must also see the side of justice that lives in the society.

2) The 1945 Constitution

Article 18B paragraph (2) of the 1945 Constitution which states that the state recognizes and respects the customary law community units along with their traditional rights as long as they are still alive and in accordance with the

18 Eddy O.S. Hiariej, Prinsip-Prinsip Hukum Pidana (Yogyakarta: Cahaya Atma Pustaka, 2016). 
development of society and the principles of the Republic of Indonesia, which is regulated in law. State recognition of indigenous and tribal peoples has the consequence of the recognition of customary law as a source of law. On the basis of this, of course, the source of the law to declare an act as a criminal offense, the Criminal Code should not only pass the unwritten law that lives in the community.

3) Article 5 paragraph (3) of the Emergency Law Number 1 of 1951 concerning Temporary Actions for Organizing the Unity of Power Structure and the Procedures of Civil Courts states:

that an act which according to living law must be considered a criminal act, but which is unequaled in the Civil Criminal Code, is considered to be threatened with a sentence of no more than three months in prison and / or a fine of five hundred rupiahs, that is as a substitute sentence when the traditional punishment that was dropped was not followed by the convicted party and the substitution referred to was deemed commensurate by the judge with the magnitude of the convicted error, that, if the customary sentence handed down according to the judge's mind surpasses him with a sentence of imprisonment or a fine referred to above, then for the mistake of the defendant may be subjected to a substitute sentence as high as 10 years in prison, with the understanding that the customary punishment according to the judge's understanding is no longer in accordance with the present must always be replaced as mentioned above, and that an act which according to living law must be considered a criminal act and which is comparable in the Civil Criminal Code, is considered threatened with the same sentence as the sentence which is most similar to the criminal act.

4) Article 5 paragraph 1 Law No. 48 of 2009 concerning Judicial Authority states that a judge and constitutional judge required to research, follow, and truly understand the values of law and the sense of justice that lives in the community can also be the source in enforcing the law whether it's still at the investigation process, prosecution, or even trial.

Other articles in the criminal code also have to be validated before it is implemented is the adultery offence in acticle 284 of the criminal code. Article 234 of the criminal code defines adultery if the act is done by someone who is already married. Adultery is one of the morality offences that is still closely related to the sacred values of the institution of marriage. So the central problem lies in the views and concepts of values of the community/citizens regarding the values of decency and the sanctity of the marriage 
institution itself. The views and concepts of values of a more individualistic and liberalistic society are, of course, different from the more familial, collectivistic and monodualistic views of society. ${ }^{19}$.

With that being said, the meaning of adultery will surely be different if the concept of value that one community hold is different. The criminal code comes from the values of a individualistic and a liberalistic sociey. Of course the meaning of adultery does not act in accordance with the National Law System that is tied with Pancasila, consists of a more familial, collectivistic and monodualistic values. For the God-nation of Indonesia, of course the meaning of adultery is not only for those who are bound by marriage but also for those who are not bound by a marriage that committed intercourse.

In addition to the two articles above, namely Article 1 paragraph (1) and Article 284, other articles in the Criminal Code should also be validated before they are applied in Indonesia. This is important to be carried out as the wish desired by the 1945 Constitution and various other laws and regulations.

c. Implementation Of Articles In The Criminal Code Have To Be In The Indonesian Text

Regarding such restrictions can be concluded from Moeljatno's view of Law No. 1 of 1946 can be used to explain how to run / implement the Criminal Code, as follows: ${ }^{20}$

"....But regarding the meaning of article V of Law No. 1 of 1946 earlier, which was born in the arena of revolution, where the explosion of mortars and whirring rifle bullets, still endanger the lives of the Republic of Indonesia government officials on the Jakarta-Yogyakarta train journey, the country's capital at that time, the Revolution (in the current condition it can be read: "development" or "current reform", bna) in the field of legal system requires the elimination of all things that are decayed and obsolete, to be replaced with a fresh useful and progressive, then the formal juridical way of thinking earlier should be replaced with material juridical in the sense that the words used in the regulation, should be interpreted so that the meaning of the regulation becomes very appropriate and in tune with the dynamics and progressiveness of the community where the regulation is expected to benefit. The words in the rules are important and are a limit for understanding rather than fill out the regulations. But this limit must not be set at a minimum, meaning only remembering vorm or the equivalent of the regulation, even if it needs to be expanded to the maximum, so that the rule is not felt either directly or indirectly as a barrier at least uselessly towards the completion of our revolution ".

19 Barda Nawawi Arief, Bunga Rampai Kebijakan Hukum Pidana: Perkembangan Penyusunan Konsep KUHP Baru (Jakarta: Prenada Media Grup, 2016).

20 Arief, Complementary Criminal Law I. 
Moving on to Moeljatno's view, Barda Nawawi Arief concluded that Moeljatno believed not to be merely juridical formal thinking (textual minimalism), but should be extended to juridical material according to the dynamics / progression of society or in other words towards contextual / substantive maximal thinking. He was thus impressed by his stance that the enforcement of criminal law (especially the Penal Code of the Dutch heritage) should remain in the Indonesian context. ${ }^{21}$

In the context of Indonesia, Indonesia is an independent country. As an independent country, Indonesia is fully sovereign of all laws (including criminal law) that will be enforced. After independence, the Criminal Code is within the framework of the National Legal System (national legal system). In the Indonesian context, the national legal system is none other than the National Law System-Pancasila. The National Law SystemPancasila is further elaborated through the establishment of the basic law contained in the 1945 Constitution of the Republic of Indonesia, which is then regulated further in various laws and regulations.

As part of the National Law System-Pancasila, the norms in the Criminal Code that are to be enforced should be based on Pancasila, namely the Almighty God, Humanity that is just and civilized, Indonesian Unity, Society led by wisdom wisdom in Consultation / Representation and Social Justice for all people of Indonesia. By Barda Nawawi Arief, the philosophical foundation of the Pancasila embodies the National Law System is compacted into 3(three) pillars, i.e : ${ }^{22}$ : 1) Oriented to the values of "God" (religious moral); 2) Oriented to the values of "Humanity" (humanistic); and 3) Oriented to the values of "Society" (nationalistic; democratic; social justice).

Thus, if there are norms in the Criminal Code that are not oriented to the pillars mentioned above, then it can be said that it is not a National (Criminal) Law System. ${ }^{23}$. But unfortunately these values are often forgotten. Even revealed that the spirit of "nationalism in enforcement" is what seems to be declining / fading in the practice of criminal law up to now, because it prioritizes / prioritizes the norms and values contained in WvS over the signs of the national law enforcement system (both contained in the Constitution and in national legislation products).

\footnotetext{
Ibid.

Arief, Perkembangan Sistem Pemidanaan Di Indonesia. Ibid.
} 
In the level of law enforcement practices that are not in line with the National Law System signs, it can be seen from the emergence of 'justice mafia', 'case brokers', 'corruption', 'bribery', and so on. ${ }^{24}$. The rise of the problem is caused by the Pancasila and the 1945 Constitution not being guidance in law enforcement, but rather being guided by economic rationality. In his dissertation, Teddy Asmara revealed ,. Such rationality is patterned as a legal economic culture, accepted, agreed upon and practiced by the judge community. ${ }^{25}$. In other words, law enforcement is currently influenced by Economic Culture, which is full of negotiations, compromises, transactions, and even commercialization in the judiciary in Indonesia. The results of a study released by the Corruption Eradication Commission in October 2017 provided evidence of this problem in law enforcement in Indonesia: ${ }^{26}$ :

Buying and selling cases with the intention of alleviating or freeing those who are entangled in legal cases has become common knowledge. Case mafia thrives in law enforcement institutions in Indonesia from the lowest to the highest level ... Although Indonesia is affirmed as a state of law, law sometimes experiences gathering in large cases involving "influential people "or those who have funds to" buy the law". It's as if the legal case is sugar and is swarmed by a pack of ants. The law turns into a commodity that can be traded, especially for those who have enough money to regulate the case that wraps it. The law enforcers also applies coincidental situation to benefit from people who are caught in a legal case.

In the following year, year 2018, Indonesian Corruption Watch explained the Watch explained the existence of corruption in various institutions, one of which is a court institution. There were 4 (four) cases with a bribe value of Rp. 5.7 Billion. ${ }^{2728}$. The values of "God", the values of "Humanity" and the values of "Society as the soul of law enforcement are important because of economic rationality." For Milton L. Myers that rationality is the same as serving of self-interest through the maximization of wealth and want satisfaction. Full self-interest is based only on the moral equivalent of the force of gravity in nature. $^{29}$

Artidjo Alkostar, "Problems of the Judicial Mafia and Countermeasures," Journal of Law 21, no. 9 (2002): 1.

Teddy Asmara, Budaya Ekonomi Hukum Hakim (Semarang: Fasindo, 2011).

26 Komisi Pemberantasan Korupsi, Our Corruption Story: Anatomy of Major Cases in Interdisciplinary Studies (Jakarta: Komisi Pemberantasan Korupsi, 2017).

27 Indonesia Corruption Watch, "Report on Corruption Case Enforcement in 2018" (Jakarta, 2018).

28 Komisi Pemberantasan Korupsi, "Corruption Eradication Commission, 2018 KPK Annual Report" (Jakarta, 2018).

29 Ali Amin Isfandiar, "Melacak Teori Rasionalitas Ekonomi Berbasis Islamic Ethics," MUQTASID Jurnal Ekonomi Dan Perbankan Syariah 6, no. 2 (2015): 23. 
In addition, in small cases the application of the article in the Criminal Code only fulfills the formulation of the law, not paying attention to the divine, humanitarian and social values as contained in Pancasila. Just to mention one of them is the theft of 3 (three) cocoa (chocolate) by an elderly woman named Minah. It is interesting to note the chronological description of the case events as conveyed by Widodo Dwi Putra as follows: ${ }^{30}$

The case began one day in August 2009, an elderly grandmother from Darmakradenan Village, Ajibarang District, Banyumas, Central Java, harvesting soybeans on her arable land. Bordered by a cocoa farm (in the area commonly known as chocolate) owned by PT RSA, while harvesting soybeans, Min's grandmother's eyes saw brown trees that had a lot of fruit and ripe. Min picked three chocolates in the garden, then put them in place. There was no intention of him to hide it and no intention in his mind to take him away. As in the interview; "Inyong seq teng kebon, enten coffee-mateng inyong pendhet is located with eng engiti siti (I am in the garden, I have ripe cacao taken and placed on the ground)," (interview with Min, March 10, 2010). Not long after, through a foreman PT RSA cocoa plantation. The foreman also asked, who picked the cocoa fruit. Innocent, Min claimed it was his doing, as told; "Mandor tanglet; sinten sing mendet kopi- coklat? Jawab inyong, ajeng nggewinih, angsal mboten ?" , "Nek Mboten angsal, nggih dibekto mriko (the foreman asked, who took cocoa. My answer is to be used as seeds. If not allowed, please take it there. (Interview with Min, March 11, 2010). The foreman then gave a lecture that his actions included theft. Min then apologized to the foreman and promised not to do it again. He handed over the 3 pieces of cocoa he handed over to the foreman. Grandmother Min thought everything was all right and she went back to work. A week later, Min was summoned and interrogated by the police at the Ajibarang Police Station. From the results of the investigation, the police concluded that Min's actions fully met the elements mentioned in Article 362 of the Criminal Code which were formally categorized as criminal acts of theft. Without realizing what was really happening, Grandma Minah, who was not only illiterate, but also legal illiterate, was not accompanied by a lawyer, Min confirmed what the police had written in her case report and what the prosecutor wrote in her indictment. Min also had to undergo house arrest so that as a farmer he could no longer work in his fields. The legal process continued until finally he had to sit as a defendant in a theft case in the Purwokerto District Court. Min was on trial without being accompanied by a lawyer and he claimed not to know the twists and turns of the court proceedings, with procedures that are formally regulated in Indonesian which throughout his life lived in the village and only, using Javanese in everyday life. All that was thought about was how the case was quickly resolved. Because if not, he has to commute from his house to the prosecutor's office and the court office within 40 kilometers, so he is forced to owe angkot and ojek Rp. 50 thousand to neighbors each time undergoing examination (interview with Min, March 12, 2010).

30 Widodo Dwi Putro, "Looking for Material Truth in 'Hard Case' Theft of Three Cocoa Fruit: Study of Decision Number 247 / Pid.B / 2009 / PN.PWT,” Judicial Journal 3, no. 3 (2010). 
The law enforcement of the provisions of Article 362 of the Criminal Code in such cases is seen as merely reading the formulation of norms, and not caring about human values. This has escaped the criminal law enforcement process in Indonesia. Regarding law enforcement, it is important to pay attention to what Andrew Ashworth and Jeremy Holder said: The chief concern of the criminal law is to prohibit behavior (melarang perbuatan) that represents a serious wrong (kesalahan serius) against an individual or against some fundamental social value or institution (nilai atau institusi sosial fundamental). ${ }^{31}$. It is also interesting what was conveyed by Paul J. and Patricia L. Brantingham as 'environmental criminology' assumes that "criminal events must be understood as confluences of offenders, victims or criminal targets, and laws in specific settings at particular times and places. ${ }^{32}$. In other words, it can be concluded that criminal sanctions should only be imposed on acts that are very serious and contrary to the fundamental values believed by society.

\section{Conclusions}

Based on the above it can be concluded that the enactment of the Criminal Code in Indonesia must be in the Indonesian context. This means that the enactment of the Criminal Code cannot be implemented in letterlijk, but rather pay attention to the signs of the National Law System namely Pancasila, the 1945 Constitution, Law No. 1 of 1946, Government Regulations No. 2 of 1945 and various other laws and regulations. From the various laws and regulations it is known that the limitations of the enactment of the criminal code draft include, first, the enactment of the Criminal Code is temporary until the Criminal Code is established based on the 1945 Constitution. The House of Representatives of the Republic of Indonesia together with the Government of the Republic of Indonesia must immediately ratify a long draft Law on the Criminal Code. Second, there is a need to examine the norms of criminal law in the Criminal Code before they are applied (whether the criminal law norms are in accordance with the criteria "does not contradict to the standing of the Republic of Indonesia as an independent country or does not contradicts with the constitution"), and third, the application of the articles in The Criminal Code must remain in the Indonesian context.

\footnotetext{
Andrew ; Jeremy Holder Ashworth, Principles of Criminal Law (Oxford: Oxford University Press, 2013).

32 Anna; Shigeo Tatsuki Matsykawa, "Crime Prevention through Community Empowerment: An Empirical Study of Social Capital in Tokyo," International Journal of Law, Crime and Justice 54, no. September (2018): 89-101.
} 


\section{References}

Alkostar, Artidjo. "Problems of the Judicial Mafia and Countermeasures." Journal of Law 21, no. 9 (2002): 1.

Arief, Barda Nawawi. Bunga Rampai Kebijakan Hukum Pidana: Perkembangan Penyusunan Konsep KUHP Baru. Jakarta: Prenada Media Grup, 2016.

- Complementary Criminal Law I. Semarang: Pustaka Magister, 2012.

—. Perkembangan Sistem Pemidanaan Di Indonesia. Semarang: Master Library Publisher, 2011.

Ashworth, Andrew; Jeremy Holder. Principles of Criminal Law. Oxford: Oxford University Press, 2013.

Asmara, Teddy. Budaya Ekonomi Hukum Hakim. Semarang: Fasindo, 2011.

Bentham, Jeremy. "Paper Relative to Codification and Public Instruction: Including Correspondence with the Russian Emperor, and Divers Constituted Authorities in the American United States, No. XII.” Jeremy Bentham to Emperor of the All Russias, Letter II, n.d.

Bowring, John. "The Works of Jeremy Bentham, Vol. 4." The Superntedence of His Executor, n.d.

Finbar McAuley, Et.al. "Codifying the Criminal Law, Expert Group on the Codification of the Criminal Law.” Dublin, 2004.

Hiariej, Eddy O.S. Prinsip-Prinsip Hukum Pidana. Yogyakarta: Cahaya Atma Pustaka, 2016.

Indonesia Corruption Watch. "Report on Corruption Case Enforcement in 2018." Jakarta, 2018.

Isfandiar, Ali Amin. "Melacak Teori Rasionalitas Ekonomi Berbasis Islamic Ethics." MUQTASID Jurnal Ekonomi Dan Perbankan Syariah 6, no. 2 (2015): 23.

James T. Graves, et.al. "Perception versus Punishment in Cybercrime.” Journal of Criminal Law and Criminology 109, no. 2 (2019).

Kasirer, Nicholas. "Canada's Criminal Law Codification Viewed and Reviewed.” McGill Law Journal, 1990, 866.

Komisi Pemberantasan Korupsi. "Corruption Eradication Commission, 2018 KPK Annual Report.” Jakarta, 2018.

- Our Corruption Story: Anatomy of Major Cases in Interdisciplinary Studies. Jakarta: Komisi Pemberantasan Korupsi, 2017.

Matsykawa, Anna; Shigeo Tatsuki. "Crime Prevention through Community Empowerment: An 
Empirical Study of Social Capital in Tokyo." International Journal of Law, Crime and Justice 54, no. September (2018): 89-101.

McAuley, Finbarr. "Meeting the Challenge of Codifying the Criminal Law." In The 22nd International Conference of the International Society for the Reform of Criminal Law, 2008.

Murillo, Maria Luisa. "The Evolution of Codification in the Civil Law Legal Systems: Towards Decodification and Recodification.” Journal Transnational Law \& Policy 11, no. 1 (n.d.): 3.

Putro, Widodo Dwi. "Looking for Material Truth in 'Hard Case' Theft of Three Cocoa Fruit: Study of Decision Number 247 / Pid.B / 2009 / PN.PWT.” Judicial Journal 3, no. 3 (2010).

Sahetapy, J.E. Legal Reform Must Embody the Pancasila, in the Judicial Commission of the Republic of Indonesia, Dialectics for the Renewal of the National Legal System. Jakarta: Secretariat General of the Judicial Commission of the Republic of Indonesia, 2012.

Tetley, William. "Mixed Jurisdiction: Common Law vs Civil Law (Codified and Uncodified)." Unif. L. Rev 3 (1993): 596.

Wilson, William. Criminal Law. London: Perason Education Limited, 2017.

Wright, Barry. "Bentham's Enlightened Despotic Legislator and Colonial Rule: Macaulay and India Penal Code." In A Model Penal Code Adhering to the Philosophy of Macaulay: A Project to Mark the 150th Annivarsary of the Indian Penal Code., 1, 2010. 